\title{
Burnout Levels of EFL Instructors in Relation to Organizational Context
}

\begin{tabular}{|c|c|}
\hline \multicolumn{2}{|c|}{ Department of English Language Education, Bahcesehir University, Istanbul, Turkey } \\
\hline Article history & T The purpose of this study is to investigate the burnout levels of English \\
\hline $\begin{array}{l}\text { Received: } \\
08.12 .2015\end{array}$ & $\begin{array}{l}\text { as Foreign Language (EFL) instructors at foundation universities in } \\
\text { Istanbul, and also, explore whether there are any differences between low }\end{array}$ \\
\hline $\begin{array}{l}\text { Received in revised form: } \\
19.12 .2015\end{array}$ & $\begin{array}{l}\text { and high burnout EFL instructors in terms of their organizational context. } \\
\text { This study aims to find the answers for these research questions: (1) to } \\
\text { what extend is the level of job burnout perceived by EFL instructors? }\end{array}$ \\
\hline $\begin{array}{l}\text { Accepted: } \\
21.12 .2015\end{array}$ & \\
\hline Key words: & three dimensions of) burnout and (the six areas of) worklife? If so, what \\
\hline $\begin{array}{l}\text { Burnout, Teacher Burnout, } \\
\text { English as a Foreign Language } \\
\text { (EFL), EFL Instructors, MBI- } \\
\text { ES, AWS }\end{array}$ & $\begin{array}{l}\text { might be the reasons behind this difference? A sample of eighty-one EFL } \\
\text { instructors ( } 22 \text { male and } 59 \text { female) participated in this study. The } \\
\text { quantitative data were obtained through The Maslach Burnout Inventory } \\
\text { - Educators Survey (MBI-ES) and Areas of Work life Survey (AWS) } \\
\text { questionnaires while the qualitative data were collected from semi- } \\
\text { structured interviews administered to eighteen volunteer instructors. The } \\
\text { findings of the study showed that most of the instructors had moderate } \\
\text { and high levels of emotional exhaustion, depersonalization, and only a } \\
\text { quarter of participants had higher sense of personal accomplishment. On } \\
\text { the other hand, EFL instructors who reported high levels of burnout had a } \\
\text { significantly more negative perception of the organizational environment } \\
\text { they worked in. The findings of the study were discussed in relation to } \\
\text { different dimensions of burnout affecting different domains of work } \\
\text { environment. }\end{array}$ \\
\hline
\end{tabular}

\section{Introduction}

Accomplishing what is expected to do in a job is a necessity for every employee and doing this in an efficient way is the preferable path. One needs to be eager to work, have the energy, and a fresh mind to do what needs to be done. Like any other job, this is true for teachers, too. However, this is not always the case. In point of fact, teaching is a stressful profession (Borg \& Riding, 1991; Travers \& Cooper, 1996). High levels of exhaustion and cynicism exist in teachers when compared to other professions (Maslach, Jackson, \&Leiter, 1996).

The term "burnout" in social sciences was first coined by Freundenberger. Referring to dictionary definition, he described burnout as "to fail, wear out, or become exhausted by making excessive demands on energy, strength, or resources" (Freundenberger, 1974, p. 159). Cherniss (1980) defined burnout as a response to chronic difficulty in dealing with stress. As

*Correspondence: yesimkeslidollar@gmail.com 
a catchy metaphor for the draining of energy, burnout refers to the smothering of a fire or the extinguishing of a candle. It implies that once fire was burning but the fire cannot continue burning brightly unless there are sufficient resources that keep being replenished (Schaufeli, Leiter, \&Maslach, 2009). Burnout is a work-related syndrome, and stems from an individual's perception of a significant discrepancy between effort (input) and reward (output), and this perception is being influenced by individual, organizational, and social factors. It occurs most often in those who work face to face with troubled and needy clients (Farber, 1991).

Being a multidimensional phenomenon, burnout is a syndrome consisting of emotional exhaustion, depersonalization, and reduced personal accomplishment (Maslach et. al., 1996). Depersonalization is characterized as withdrawing from others and becoming negative. Feeling a lack of accomplishment and that one's work is not successfully achieved is defined as reduced personal accomplishment (Maslach \& Jackson, 1981).

\section{Literature Review}

Rapidly changing and more demanding work environment accompanied by the technological changes lead to more job stress. When it is an unresolved and consistent situation and there is a mismatch between the job and the individual, the probable result is burnout. Burnout is both related to physical and mental health. In point of fact, it is linked with major adverse health effects for people who suffer from it (Cordes \& Dougherty, 1993). People who suffer from burnout develops negative job attitudes, poor professional selfconcept, and low emphatic concern for clients (Maslach \& Pines, 1984). Therefore, it affects job performance and results in less effective practice of work. As a consequence, burnout deteriorates the relationship with other people at work. Therefore, it is crucial that this syndrome to be investigated so that it is understood clearly and necessary actions are taken against this syndrome. A better understanding of burnout syndrome would help institutions and it could also suggest prevention ideas to solve the related problems before they happen.

Maslach and Leiter (1999) argue that like other human service professions, teaching also shares a close relationship with recipients (e.g., students) but teaching differs in terms of its relationship with recipients: While other professions have a more individual focus, teaching constitutes a relationship between a classroom where teachers need to deal with different students at the same time. Moreover, school realities are also related to teacher burnout. For instance, Lavian (2012) found that teachers started their jobs with idealistic beliefs, a faith in their own abilities, and a willingness to work hard, but later they became disappointed when they faced school realities. Therefore, stressful nature of teaching leads the way to burnout considering the environment where teachers have to deal with many different stressors at work (e.g., difficult classes, unsupportive administrational decisions, and parents).

Like other professions, teachers also experience dimensions of burnout. With respect to empirical evidence in teaching domain, Byrne (1999) stated that emotional exhaustion occurs first and it causes depersonalization, on the other hand, reduced personal accomplishment develops separately. Maslach and Leiter (1999) argue that this parallel development in dimensions may be the result of different factors in work environment (e.g., work overload, personal conflict, and social support). Teachers feel emotionally exhausted when their energy is drained and they think they cannot give or be useful for their students anymore (Byrne, 1994). These burned-out teachers perceive themselves less effective in their work and experience reduced personal accomplishment feeling that they are inadequate (Maslach \& Jackson, 1986). 
There are several causes of teacher burnout. Burke, Greenglass and Schwarzer (1996) found that multiple and contradictory roles, maintaining classroom decorum, attending to students social and emotional well-being, meeting the conflicting expectations of parents, students, administrators, and community, disruptive students, lack of supervisor support, lack of social integration, job related self-doubt, and red tape are some causes of teacher burnout. They also found that red tape and disruptive students were the strongest predictors of teacher burnout.

Pioneering studies on teacher burnout in Turkey began in mid-90s. These studies included elementary school teachers, high school teachers and later special education teachers. In the past decade, research has also been carried out on academic personnel, physical education teachers and instructors at universities. Girgin (1995) examined teacher burnout among elementary school teachers by making use of MBI-Educators Survey and a questionnaire on personal and work-related information. According to her study, emotional and reduced personal accomplishment levels of men and women didn't differ. However, women showed lower levels of depersonalization. She also found that as teachers got older, they felt lower levels of emotional exhaustion and depersonalization but higher accomplishment in their jobs.

Other than elementary school teachers, Baysal (1995) explored factors related to burnout among high school teachers. MBI-Educators Survey and a questionnaire on demographic and work related information were used. The findings showed that women were suffering emotional exhaustion and younger teachers experienced more emotional exhaustion and depersonalization. Teachers who chose the teaching profession because they loved it showed lower levels of burnout than those teachers who had different reasons. Besides, teachers who thought they had support from administrators and colleagues experienced low levels of burnout.

The effects of some organizational factors are examined in another research study, and this study indicates that organizational factors in schools should also be studied in relation to burnout. Accordingly, Demir (1997) explored the job stress of teachers and principals in secondary education schools. The findings showed that inadequate salaries are the most stressful factor related to job structure for both teachers and principals. Working hours and heavy workload were the second and the third most stressful factors. In another research, class size and working conditions were also studied together: Cihan (2011) investigated job burnout levels of physical education teachers working at different cities. He also compared working conditions of these teachers. He found that women felt more emotional exhaustion and less depersonalization than men. Moreover, the level of burnout of teachers who had crowded classes was higher than the ones who had less crowded classes. The social and economic situation of the city in which teachers worked also highly influenced burnout level.

Some recent studies also include English teachers at university level and academic personnel. With regard to this, Polatlı (2007) investigated the burnout levels of academic personnel in Gaziosmanpaşa University, to evaluate the relationship between some variables and academic personnel's burnout level. She found academic personnel reported moderate levels of emotional exhaustion and depersonalization, but high level of reduced personal accomplishment. On the other hand, Kulavuz (2006) investigated the relationship between burnout and professional learning activities among Turkish EFL Instructors working at preparatory programs in Istanbul. She found that state university English prep program instructors had significantly lower sense of personal accomplishment and lower levels of participation in professional learning activities compared to private university English preparatory program instructors. Moreover, a positive correlation between personal 
accomplishment and participation in professional learning activities was found.

Finally, Atila (2014) examined the relationships between burnout and job satisfaction levels among English teachers working at primary, secondary and high schools affiliated to Ministry of National Education and English instructors working at state universities. She examined burnout and job satisfaction levels in terms of gender, weekly course load, experience, graduated department, average number of students per class, educational status and the length of the period in the current institution. She also examined whether the findings in these teachers differed. She found negative correlation between burnout and job satisfaction, no significant impact of gender, graduated department, professional experience, educational status, weekly course load and experience in the current institution on individuals' intrinsic and extrinsic job satisfaction.

These examples of teacher burnout research studies in Turkey show that university level studies compared to other levels of education are relatively few and further research can contribute to understanding of burnout among instructors and academicians. Research studies that consider job-person match to suggest prevention ideas can benefit teacher burnout research in Turkey, and to the researcher's knowledge, there is no study in Turkey that investigated organizational factors causing teacher burnout in the view of this job-person match,

Like any other human beings, teachers also feel down (e.g., feel stressful) and come to the point of giving up (e.g., quitting the job because feeling burned out) time to time. In fact, their well-being is tied to different factors. Therefore, this study will contribute the literature by investigating the burnout experienced by teachers along with its causes.

Since teaching profession is excessively demanding, requires effective communication, and leads one to suffer from emotional burnout, it is acknowledged as one of the professions with a great likelihood of burnout (Seferoğlu, Y1ld1z, \&Yücel, 2014). Therefore, the three aspects of burnout is closely related to a teacher's psychological and physical well-being, perceptions of their job, and how they deal with it.It is necessary to maintain teacher's well-being so that they can provide students a good learning environment. Consequently, teacher burnout in relation to work areas is an important matter that needs to be taken into account.

Organizational context (e.g., decisions made by administration, relationship between colleagues) also affects the way how teachers perceive their work. Therefore, it is crucial that teacher burnout is explored in a contextual perspective, where not only the burnout levels of teachers should be investigated but also the work related reasons and their perceptions by teachers need to be explored for a better understanding of EFL teachers' working conditions. Therefore, the main aims of this study are to find out level of job burnout perceived by EFL instructors working at preparatory schools and its relation to organizational context according to a job-person match/mismatch model. Therefore, the study aims at exploring the difference between EFL instructors with low and high burnout in terms of work related areas.

In the light of above discussion, this study aims to find the answers for these research questions:

(1) To what extend is the level of job burnout perceived by EFL instructors?

(2) Is there a significant difference between EFL instructors experiencing high and EFL instructors experiencing low burnout in terms of (each three dimensions of) burnout 
and (the six areas of) work life? If so, what might be the reasons behind this difference?

\section{Methodology}

\subsection{Research Design}

In scope of this study, a non-experimental quantitative research design, namely, survey research was used. Fowler (2008) defines survey research design as follows (as cited in Creswell, 2013):

Survey research provides a quantitative or numeric description of trends, attitudes or opinions of a population by studying a sample of that population. It includes cross-sectional and longitudinal studies using questionnaires or structured interviews for data collection - with the intent of generalizing from a sample to a population (p.13.)

This study is also cross-sectional because the data was gathered at one point in time to explore burnout levels of EFL instructors. Aims of this study also fit for a qualitative research design. In this study, participants views on burnout and organizational factors leading to burnout were investigated. Therefore, it is a phenomenological study that "tries to understand a small, selected group of people's perceptions, understandings, and beliefs concerning a particular situation or event" (Cottrell \& McKenzie, 2010, p. 10).

\subsection{Setting}

The study was carried out with EFL instructors employed at English preparatory programs at five foundation universities in Istanbul, in 2014-2015 academic year. University English preparatory programs offer one year intensive English program. Students are placed according to their levels in these programs after a placement test in the beginning of each academic year based on Common European Framework of Reference (CERF). It is aimed that after completing these programs, students will be able to follow their courses at their departments, as classes at their respective departments are held in English.

\subsection{Participants}

The sample in this study consisted of 81 EFL instructors working at English preparatory programs at five different foundation universities in Istanbul.

Table 1 below shows the distribution of 81 respondents:

Table 1. Overview of the Participants

\begin{tabular}{lccc}
\hline Categories & & F & $\%$ \\
\hline Age & $24-30$ & 52 & 64.2 \\
& $31-35$ & 13 & 16 \\
& $36-40$ & 9 & 11.1 \\
Gender & Over 40 & 7 & 8.6 \\
& Female & 22 & 27.2 \\
Work Status & Male & 59 & 72.8 \\
& Full-time & 73 & 90.1 \\
Number of Years & Part-time & 8 & 9.9 \\
Worked in Total & $1-5$ & 41 & 50.6 \\
& $6-10$ & 25 & 30.9 \\
& $11-15$ & 8 & 9.9 \\
Number of Years & $16-20$ & 4 & 4.9 \\
Worked in Current & Over 20 & 3 & 3.7 \\
& $1-5$ & 72 & 88.9 \\
& $6-10$ & 6 & 7.4
\end{tabular}




\begin{tabular}{lccc} 
University & $11-15$ & 2 & 2.5 \\
& $16-20$ & 1 & 1.2 \\
Educational & Over 20 & 0 & 0 \\
Background & B.A & 17 & 21 \\
& M.A in progress & 34 & 42 \\
& M.A & 23 & 28.4 \\
Extra Job & Ph.D. in progress & 6 & 7.4 \\
Responsibilities & Ph.D. & 1 & 1.2 \\
Total & Yes & 12 & 14.8 \\
\hline
\end{tabular}

18 instructors also volunteered to take part in semi-structured interviews. Of the 18 instructors, 4 were male and 14 were female. The ages of the interviewees ranged from 27 to 41 with an average of 30.7 and the range of their total teaching experience was 2 to 17 with an average of 4.6 years of experience. On average, they have been teaching at their current schools for 2.7 years.

\subsection{Sources of data}

A three-part questionnaire and a semi-structured interview were used as the sources of data in this study.

Part 1 of the questionnaire classified the EFL instructors into various demographic categories. Pat 2 of the questionnaire was Maslach Burnout Inventory - Educators Survey. The Maslach Burnout Inventory (MBI) developed by Maslach and Jackson (1981) is widely used in burnout research. It was originally designed for human service employees. Another version, The Maslach Burnout Inventory - General Survey (MBI-GS), was developed for employees in different occupations. The Maslach Burnout Inventory - Educators Survey (MBI-ES) (Maslach, Jackson, \&Leiter, 1996), on the other hand, was designed for use by educational occupations.

In this research, MBI-ES (Maslach, Jackson, \&Leiter, 1996) was used to measure teachers' burnout levels. MBI-ES measures burnout via three distinctive subscales for the dimensions of burnout, namely emotional exhaustion (9 items), depersonalization (5 items) and personal accomplishment (8 items). Burnout for these three dimensions is scored separately, which means that there is not a combined score for burnout. High scores on emotional exhaustion and depersonalization and low scores on personal accomplishment reflect a high degree of burnout. MBI-ES Scoring Key in the Maslach Burnout Inventory Manual (Maslach, Jackson, \&Leiter, 1996) gives the instructions on how to calculate summative scores for each dimension. Table 2 illustrates the scores that would place a respondent in high, moderate and low burnout in three mentioned dimensions.

Table 2. Summative Scores for Burnout Dimensions from MBI-ES Scoring Key

\begin{tabular}{cccc}
\hline & High & Moderate & Low \\
\hline Emotional Exhaustion & 27 or over & $17-26$ & $0-16$ \\
Depersonalization & 13 or over & $7-12$ & $0-6$ \\
Personal Accomplishment & $0-31$ & $32-38$ & 39 or \\
& & & over \\
\hline
\end{tabular}

Part 3 of the questionnaire is Areas of Work life Survey. The possible mismatches between a person and his or her job are assessed by The Areas of Work life Survey (AWS) (Leiter\&Maslach, 2011). AWS comprises 28 items that produce distinct scores for each of the 
six areas of work life: Workload (5), Control (4), Reward (4), Community (5), Fairness (6), and Values (4). Items on AWS are worded as statements of perceived congruence or incongruence, for example, "I am a member of supportive work group" (community) and "My efforts usually go unnoticed" (reward). With a 5-point Likert-type scale ranging from 1 (Strongly Disagree), through 3 (Hard to Decide), to 5 (Strongly Agree), respondents indicate their degree of agreement with the statements in AWS. The Scoring Key for AWS gives the instructions on how to calculate the scores for each work area.

In addition, semi-structured interviews were carried out to get more detailed information on participants' perceptions of their work life. Interview questions were constructed in accordance with each subscale of AWS. In addition to these, an open ended question was also asked to give freedom so that participants can also comment on other things that they would like to share about their work environment.

\subsection{Data collection procedures}

5 foundation universities in Istanbul were included in this study. All the data were collected anonymously through Google Forms. Participants were also asked if they would like to participate in the interviews. A total of 84 questionnaires were submitted online and 3 of these questionnaires had some missing information and excluded from the data. 81 of the questionnaires were valid.

Semi-structured interviews were also carried out with the 18 instructors volunteered to participate. 10 of these instructors took part in e-mail interviews and 8 of them were interviewed at a time and location of their choice. Interviews were recorded and the researcher also took small notes to identify different work areas that respondents mentioned.

\subsection{Data analysis procedures}

The quantitative data analysis was done through SPSS 20.0. MBI-ES items for each subscale were transformed to low, moderate or high burnout categories through Microsoft Office Excel 2013 in line with the scoring keys of the questionnaire. To test the reliability of the questionnaires, Cronbach's alpha is also utilized. Cronbach's alpha for the entire MBI scale is 0.74 and Cronbach's alpha for the entire AWS scale is 0.84 . The closer the results moved toward one, the stronger the mismatch was between the person and his or her environment. However, moving closer to five meant the match was stronger between the person and his or her environment.

The results of MBI-ES provided the data for the first research question. This research question investigated the burnout levels of EFL instructors in terms of emotional exhaustion, depersonalization and personal accomplishment.

Data for the first part of the question were gathered through questionnaires. The aim was to investigate if there was a significant difference between low and high burnout teachers on three dimensions of burnout. Consequently, the sample was divided into two groups, based on their scores of MBI. Teachers who had low burnout scores on three dimensions of burnout constituted low burnout group (representing engagement with their work) and teachers who had moderate and high scores constituted high burnout group (representing burnout). Two group means were compared to determine whether they were significantly different from each other. Consequently, an independent samples t-test was run to examine whether there was a significant difference between each area of worklife and low and high burnout teachers. 
One assumption of an independent samples t-test is the normality requirement so it was checked via Shapiro-Wilk test. This assumption poses that if two populations are approximately normally distributed, normality requirement is met (Vaughan, 2001). However, as this research study had only sample data, the sample data needed to be checked whether the data were normally distributed or deviated from normality. So when the assumption was met, it meant that participants filled the questionnaire seriously and gave consistent answers. However, when the requirements of the t-test were not met, the data was converted into ordinal form and the Mann-Whitney U test was conducted as a nonparametric counterpart of the independent samples t-test (Vaughan, 2001).

Another assumption of an independent samples t-test is that "the standard deviations of the two samples must be fairly similar" (Vaughan, 2001, p.122). This is homogeneity of variance. When homogeneity of variance requirement is met, the variances (variability) in two groups are equal. This assumption was examined by the Levene's test. When the Levene's test was not significant $(\mathrm{p}>.05)$, equal variances were assumed and when the Levene's test was significant $(p<.05)$, equal variances weren't assumed (the assumption was violated).

As for the second part of the research question, formal semi-structured interviews were also conducted to explore the possible reasons for the difference. The questions in the interview were predetermined so they comprised six areas of worklife and general work environment. 18 instructors volunteered to take part in the interviews from 4 different universities. 8 faceto-face and 10 e-mail interviews were carried out. Participants were asked to answer the questions as detailed as possible for the e-mail interviews. For the qualitative data analysis, audio-recorded face-to-face interviews were partially transcribed and e-mails were analyzed to group the ideas under the same categories through content analysis. All the interviews were conducted in English. Interviews provided the qualitative data for the study. In the process of open coding, the qualitative data were read again and again and some generalizations were made by two raters for interrater reliability purposes. Data from these interviews were analyzed through pattern coding and interpreted accordingly to "identify an emergent theme, configuration and explanation" (Miles \&Huberman, as cited in Saldana, 2009, p. 152 ).

\section{Results}

The first research question explored the burnout levels of EFL instructors in terms of the three dimensions of burnout, namely emotional exhaustion, depersonalization and reduced personal accomplishment. To find out this, MBI-ES (Maslach, Jackson, \&Leiter, 1996) was implemented and each subscale was scored separately according to MBI-ES scoring key and EFL instructors were grouped under these subscales. Tables 3, 4, and 5 present EFL instructors' levels of burnout for each subscale.

Table 3. Frequencies and Percentages of the Emotional Exhaustion Subscale

\begin{tabular}{lcc}
\hline Level & $f$ & $\%$ \\
\hline Low & 26 & 32.1 \\
Moderate & 26 & 32.1 \\
High & 29 & 35.8 \\
\hline
\end{tabular}

Table 3 shows the distribution of participants suffering from emotional exhaustion. It can be seen that the number of those not suffering from burnout was 26, constituting only $32.1 \%$ of the sampling group. 26 of the participants $(32.1 \%)$, on the other hand, showed moderate level of burnout meaning that they have a tendency to suffer from burnout. The remaining 29 participants $(35.8 \%)$ displayed high degree of burnout in emotional exhaustion subscale. As it 
can be seen from the table, EFL instructors who had feelings of high emotional exhaustion were a bit more than the other two groups.

Table 4. Frequencies and Percentages of the Depersonalization Subscale

\begin{tabular}{lcc}
\hline Level & $f$ & $\%$ \\
\hline Low & 34 & 42.0 \\
Moderate & 31 & 38.3 \\
High & 16 & 18.8 \\
\hline
\end{tabular}

Table 4 displays the distributions of EFL instructors on depersonalization subscale of burnout. The largest number (34) of participants experienced low level of depersonalization with $42 \%$. $38.3 \%$ of the participants had moderate level of burnout in depersonalization. Only 16 people $(18.8 \%)$ had high level of depersonalization, which was the smallest group

Table 5. Frequencies and Percentages of the Personal Accomplishment Subscale.

\begin{tabular}{lll}
\hline Level & $f$ & $\%$ \\
\hline Low & 43 & 53.1 \\
Moderate & 17 & 21.0 \\
High & 21 & 25.9 \\
\hline
\end{tabular}

Scoring for the personal accomplishment subscale was calculated in the opposite direction because a low level in personal accomplishment subscale is associated with feelings of more burnout. As seen in Table 5, more than half of the participants (53.1\%) suffered from burnout in personal accomplishment subscale. 17 of participants $(21 \%)$ had moderate level of burnout. Only 21 participants $(25.9 \%$ ) had higher sense of personal accomplishment in this study.

The second research question aimed to explore if there is a significant difference between EFL instructors experiencing high burnout and EFL instructors experiencing low burnout in terms of each three dimension (emotional exhaustion (EE), depersonalization (DP), and reduced personal accomplishment (RPA)) and the six areas of work life (workload, control, reward, community, fairness, and values).

Table 6. Means and Standard Deviations of EFL Instructors with High (N=55) and Low(N=26) EE on Workload, Control, Reward, Community, Fairness, and Values

\begin{tabular}{lcccccccc}
\hline \multicolumn{10}{c}{ Groups } \\
\hline & \multicolumn{1}{c}{ EFL } & instructors with low EE & \multicolumn{3}{c}{ EFL instructors with high EE } \\
& $\mathrm{M}$ & SD & Min. & Max & M & SD & Min & Max \\
\hline Workload & 3.5077 & .64058 & 2.4 & 4.6 & 3.1527 & .71177 & 1.2 & 4.8 \\
Control & 3.8462 & .68948 & 1.75 & 5 & 3.0545 & .88282 & 1.25 & 5 \\
Reward & 3.8365 & .73465 & 2.25 & 4.75 & 3.0182 & .87116 & 1 & 4.5 \\
Community & 3.9615 & .45614 & 3.2 & 5 & 3.7273 & .58292 & 2 & 4.6 \\
Fairness & 3.8654 & .63599 & 2.16 & 5 & 3.1939 & .69519 & 1.5 & 4.66 \\
Values & 3.8942 & .79112 & 2 & 4.75 & 3.0955 & .81435 & 1.5 & 4.75 \\
\hline
\end{tabular}

As the Table 6 shows, EFL instructors with high EE scored less in all areas of work life meaning that they were less congruent with each area of work life compared to EFL instructors with low EE.

An independent samples t-test was conducted to determine if these differences between two groups were statistically significant or not. But first, as requirements for using an independent samples t-test, the normality requirement and homogeneity of variance requirement were checked. The normality assumption was checked via Shapiro-Wilk test. The test revealed that scores obtained from workload, reward and fairness were normally distributed $(\mathrm{p}>0.05)$. 
However, scores obtained from control, community and values were not normally distributed $(\mathrm{p}<0.05)$. Therefore, for the workload, reward and fairness variables, independent samples ttest was conducted. However, as the requirements of the t-test were not met (normality was not assumed), the nonparametric counterpart of the t-test, Mann-Whitney $U$ test was conducted for control, community and values variables.

Table 7. T-test Results for the Difference between EFL Instructors with High $(\mathrm{N}=55)$ and EFL Instructors with Low $(\mathrm{N}=26) \mathrm{EE}$ in terms of Workload, Reward, and Fairness Independent Samples Test

\begin{tabular}{|c|c|c|c|c|c|}
\hline & \multicolumn{2}{|c|}{$\begin{array}{l}\text { Levene's Test for } \\
\text { Equality of Variances }\end{array}$} & \multicolumn{3}{|c|}{ t-test for Equality of Means } \\
\hline & $F$ & Sig. & $t$ & $d f$ & Sig. (2-tailed) \\
\hline $\begin{array}{l}\text { Equal } \\
\text { variances } \\
\text { assumed }\end{array}$ & .196 & .659 & 2.161 & 79 & .034 \\
\hline $\begin{array}{l}\text { Equal } \\
\text { variances not } \\
\text { assumed }\end{array}$ & & & 2.245 & 54.157 & .029 \\
\hline $\begin{array}{l}\text { Equal } \\
\text { variances } \\
\text { assumed } \\
\text { Equal } \\
\text { variances not } \\
\text { assumed }\end{array}$ & .628 & .431 & 4.141 & 57.517 & .000 \\
\hline $\begin{array}{l}\text { Equal } \\
\text { variances } \\
\text { assumed }\end{array}$ & .533 & .468 & 4.167 & 79 & .000 \\
\hline $\begin{array}{l}\text { Equal } \\
\text { variances not } \\
\text { assumed }\end{array}$ & & & 4.303 & 53.339 & .000 \\
\hline
\end{tabular}

When Levene's test was not significant $(\mathrm{p}>.05)$, equal variances were assumed and when the Levene's test was significant $(\mathrm{p}<.05)$, equal variances weren't assumed. Levene's test for equality of variance indicates that two groups for workload $(\mathrm{F}=.196, \mathrm{p}>.05)$, reward $(\mathrm{F}=$ $.628, \mathrm{p}>.05)$, and fairness $(\mathrm{F}=.553, \mathrm{p}>.05)$ are homogenous.

The test value revealed that those EFL instructors who reported higher levels of EE $(M=$ $3.1527, S D=.71177$ ) relate significantly weaker match between their expectations and work conditions on workload than those who reported lower levels of $\mathrm{EE}(M=3.5077, S D=$ $.64058), t(79)=2,161, p=.034, d=-0.52$. As for reward, the test value revealed that those EFL instructors who reported higher levels of EE $(M=3.0182, S D=.87116)$ relate significantly weaker match between their expectations and work conditions on reward than those who reported lower levels of $\mathrm{EE}(M=3.8365, S D=.73465), t(79)=4.167, p=.000, d$ $=-1.01$. In terms of fairness, the test value revealed that those EFL instructors who reported higher levels of EE $(M=3.1939, S D=.69519)$ relate significantly weaker match between their expectations and work conditions on reward than those who reported lower levels of EE, as well $(M=3.8654, S D=.63599), t(79)=4.141, p=.000, d=-1.00$.

Before reporting the results for DP and RPA scales, it should be noted that all six work areas were tested via Shapiro-Wilk test and control, community and values variables were again 
found not to be normally distributed in terms of DP and RPA subscales. Therefore, independent sample t-test for workload, reward and fairness variables and Mann-Whitney $U$ test for control, community and values variables was conducted. Furthermore, Levene's test for all the independent sample t-tests was applied Below, the results of the findings are stated.

Table 8. Means and Standard Deviations of EFL Instructors with High $(\mathrm{N}=47)$ and Low (N=34) DP on Workload, Control, Reward, Community, Fairness, and Values

\begin{tabular}{|c|c|c|c|c|c|c|c|c|}
\hline \multicolumn{9}{|c|}{ Groups } \\
\hline & \multicolumn{4}{|c|}{ EFL instructors with low DP } & \multicolumn{4}{|c|}{ EFL instructors with high DP } \\
\hline & M & SD & Min & Max & M & SD & Min & Max \\
\hline Workload & 3.2294 & .69828 & 2 & 4.4 & 3.2936 & .71730 & 1.2 & 4.8 \\
\hline Control & 3.8235 & .65577 & 1.75 & 5 & 2.9362 & .87611 & 1.25 & 5 \\
\hline Reward & 3.7941 & .67271 & 2.25 & 4.75 & 2.9096 & .88377 & 1 & 4.75 \\
\hline Community & 3.8882 & .46760 & 3 & 5 & 3.7404 & .60565 & 2 & 4.8 \\
\hline Fairness & 3.7500 & .67076 & 2.5 & 5 & 3.1631 & 69980 & 1.5 & 4.33 \\
\hline Values & 3.7647 & .73066 & 2 & 5 & 3.0532 & .87374 & 1.5 & 4.75 \\
\hline
\end{tabular}

Table 9. T-test Results for the Difference between EFL Instructors with High (N=47) and EFL Instructors with Low (N=34) DP in terms of Workload, Reward, and Fairness

\begin{tabular}{|c|c|c|c|c|c|c|}
\hline \multicolumn{7}{|c|}{ Independent Samples Test } \\
\hline & & \multicolumn{2}{|c|}{$\begin{array}{l}\text { Levene's Test for } \\
\text { Equality of Variances }\end{array}$} & \multicolumn{3}{|c|}{ t-test for Equality of Means } \\
\hline & & $F$ & Sig. & $t$ & $d f$ & Sig. (2-tailed) \\
\hline \multirow{2}{*}{ Workload } & $\begin{array}{l}\text { Equal variances } \\
\text { assumed }\end{array}$ & .055 & .815 & -.402 & 79 & .689 \\
\hline & $\begin{array}{l}\text { Equal variances } \\
\text { not assumed }\end{array}$ & & & -.404 & 72.362 & .688 \\
\hline \multirow{2}{*}{ Reward } & $\begin{array}{l}\text { Equal variances } \\
\text { assumed }\end{array}$ & 1.991 & .162 & 4.896 & 79 & .000 \\
\hline & $\begin{array}{l}\text { Equal variances } \\
\text { not assumed }\end{array}$ & & & 5.113 & 78.764 & .000 \\
\hline \multirow{2}{*}{ Fairness } & $\begin{array}{l}\text { Equal variances } \\
\text { assumed }\end{array}$ & .205 & .652 & 3.790 & 79 & .000 \\
\hline & $\begin{array}{l}\text { Equal variances } \\
\text { not assumed }\end{array}$ & & & 3.816 & 72.972 & .000 \\
\hline
\end{tabular}

Levene's test for equality of variance indicates that two groups for workload $(\mathrm{F}=.055, \mathrm{p}>.05)$, reward $(\mathrm{F}=1.991, \mathrm{p}>.05)$, and fairness $(\mathrm{F}=.205, \mathrm{p}>.05)$ are homogenous.

The test value revealed that there was no significant difference between those EFL instructors who reported higher levels of DP $(\mathrm{M}=3.2936, \mathrm{SD}=.71730)$ and those who reported lower levels of DP $(\mathrm{M}=3.2294, \mathrm{SD}=.69828)$ on their perception of match between their expectations and work conditions on workload, $\mathrm{t}(79)=-, 402, \mathrm{p}=.689, \mathrm{~d}=0.09$. However, as for reward, the test value revealed that those EFL instructors who reported higher levels of DP $(\mathrm{M}=2.9096, \mathrm{SD}=.88377)$ relate significantly weaker match between their expectations and work conditions on reward than those who reported lower levels of DP $(\mathrm{M}=3.7941, \mathrm{SD}=$ $.67271), t(79)=4.896, p=.000, d=-1.12$. In terms of fairness, the test value revealed that those EFL instructors who reported higher levels of $\mathrm{DP}(\mathrm{M}=3.1631, \mathrm{SD}=.69980)$ relate significantly weaker match between their expectations and work conditions on reward than those who reported lower levels of $\mathrm{DP}$, as well $(\mathrm{M}=3.7500, \mathrm{SD}=.67076), \mathrm{t}(79)=3.790, \mathrm{p}=$ $.000, \mathrm{~d}=-0.85$. 
Mann-Whitney U test results for control, community and values variables are as follows: EFL instructors with high $(\mathrm{Mdn}=3)$ and low $(\mathrm{Mdn}=3.5)$ DP significantly differed in terms of control $(\mathrm{U}=345.500, \mathrm{z}=-4.372, \mathrm{p}=.000)$. In terms of values, high $(\mathrm{Mdn}=3.25)$ and low $(\mathrm{Mdn}=3.75)$ groups showed a significant difference, as well $(\mathrm{U}=447.500, \mathrm{z}=-3.387, \mathrm{p}=$ .000). However, there was no significant difference between EFL instructors with high (Mdn $=4)$ and low $(\mathrm{Mdn}=4) \mathrm{DP}$ in terms of community $(\mathrm{U}=721.000, \mathrm{z}=-762, \mathrm{p}=.446)$.

Table 10. Means and Standard Deviations of EFL Instructors with High $(\mathrm{N}=60)$ and Low (N=21) RPA on Workload, Control, Reward, Community, Fairness, and Values

\begin{tabular}{|c|c|c|c|c|c|c|c|c|}
\hline \multicolumn{9}{|c|}{ Groups } \\
\hline & \multicolumn{4}{|c|}{ EFL instructors with low RPA } & \multicolumn{4}{|c|}{ EFL instructors with high RPA } \\
\hline & M & SD & Min. & Max & M & SD & Min & Max \\
\hline Workload & 3.4286 & .68201 & 2.4 & 4.6 & 3.2100 & .71062 & 1.2 & 4.8 \\
\hline Control & 3.9881 & .61480 & 3.25 & 5 & 3.0708 & .86736 & 1.25 & 4.5 \\
\hline Reward & 3.9762 & .70225 & 2.5 & 4.75 & 3.0375 & .85100 & 1 & 4.5 \\
\hline Community & 4.0762 & .42179 & 3.2 & 5 & 3.7067 & .56505 & 2 & 4.6 \\
\hline Fairness & 3.7460 & .63600 & 2.5 & 5 & 3.2917 & .74638 & 1.5 & 4.66 \\
\hline Values & 3.8214 & 69437 & 2.25 & 5 & 3.1875 & .89090 & 1.5 & 5 \\
\hline
\end{tabular}

Table 11. T-test Results for the Difference between EFL Instructors with High $(\mathrm{N}=60)$ and EFL Instructors with Low $(\mathrm{N}=21)$ RPA in terms of Workload, Reward, and Fairness

\begin{tabular}{|c|c|c|c|c|c|c|}
\hline \multicolumn{7}{|c|}{ Independent Samples Test } \\
\hline & & \multicolumn{2}{|c|}{$\begin{array}{l}\text { Levene's Test for } \\
\text { Equality of Variances }\end{array}$} & \multicolumn{3}{|c|}{ t-test for Equality of Means } \\
\hline & & $F$ & Sig. & $t$ & $d f$ & Sig. (2-tailed) \\
\hline \multirow{2}{*}{ Workload } & $\begin{array}{l}\text { Equal variances } \\
\text { assumed }\end{array}$ & .120 & .730 & 1.225 & 79 & .224 \\
\hline & $\begin{array}{l}\text { Equal variances } \\
\text { not assumed }\end{array}$ & & & 1.250 & 36.310 & .219 \\
\hline \multirow{2}{*}{ Reward } & $\begin{array}{l}\text { Equal variances } \\
\text { assumed }\end{array}$ & .659 & .420 & 4.538 & 79 & .000 \\
\hline & $\begin{array}{l}\text { Equal variances } \\
\text { not assumed }\end{array}$ & & & 4.978 & 42.075 & .000 \\
\hline \multirow{2}{*}{ Fairness } & $\begin{array}{l}\text { Equal variances } \\
\text { assumed }\end{array}$ & .516 & .475 & 2.489 & 79 & .015 \\
\hline & $\begin{array}{l}\text { Equal variances } \\
\text { not assumed }\end{array}$ & & & 2.689 & 40.721 & .010 \\
\hline
\end{tabular}

Levene's test for equality of variance indicates that two groups for workload

$(\mathrm{F}=.120, \mathrm{p}>.05)$, reward $(\mathrm{F}=.659, \mathrm{p}>.05)$, and fairness $(\mathrm{F}=.516, \mathrm{p}>.05)$ are homogenous.

The test value revealed that there was no significant difference between those EFL instructors who reported higher levels of RPA $(M=3.2100, S D=.71062)$ and those who reported lower levels of RPA $(\mathrm{M}=3.4286, \mathrm{SD}=.68201)$ on their perception of match between their expectations and work conditions on workload, $t(79)=1,225 \mathrm{p}=.224, \mathrm{~d}=-0.31$. However, as for reward, the test value revealed that those EFL instructors who reported higher levels of RPA $(M=3.0375, S D=.85100)$ relate significantly weaker match between their expectations and work conditions on reward than those who reported lower levels of RPA ( $M=3.9762$, $\mathrm{SD}=.70225), \mathrm{t}(79)=4.538, \mathrm{p}=.000, \mathrm{~d}=-1.20$. In terms of fairness, the test value revealed that those EFL instructors who reported higher levels of RPA $(\mathrm{M}=3.7500, \mathrm{SD}=.74638)$ 
relate significantly weaker match between their expectations and work conditions on reward than those who reported lower levels of RPA, as well $(\mathrm{M}=3.7460, \mathrm{SD}=.63600), \mathrm{t}(79)=$ $2.489, \mathrm{p}=.015, \mathrm{~d}=0.00$.

Mann-Whitney $U$ test results for control, community and values variables are as follows: EFL instructors with high $(\mathrm{Mdn}=3.375)$ and low $(\mathrm{Mdn}=3.25)$ RPA significantly differed in terms of control $(\mathrm{U}=285.000, \mathrm{z}=-3.745, \mathrm{p}=.000)$. In terms of values, high $(\mathrm{Mdn}=3.5)$ and low $(\mathrm{Mdn}=4)$ groups showed a significant difference, as well $(\mathrm{U}=361.000, \mathrm{z}=-2.919, \mathrm{p}=$ $.004)$. Moreover, EFL instructors with high $(\mathrm{Mdn}=3.8)$ and low $(\mathrm{Mdn}=4)$ RPA significantly differed in terms of community $(\mathrm{U}=420.000, \mathrm{z}=-2.309, \mathrm{p}=.021)$.

To summarize the results of the independent samples t-tests and the Mann-Whitney U tests, results for each subscale of burnout and work related areas are: (1) Emotional Exhaustion: Higher levels of emotional exhaustion induced a significantly lower match between teacher expectations and work conditions on all dimensions except for community. (2) Depersonalization: The teachers who report higher levels of depersonalization relate weaker match between their expectations and work conditions on reward, fairness, control, values. Workload and community variables were not found to be significantly related. (3) Reduced Personal Accomplishment: Instructors who report lower levels of personal accomplishment relate weaker match between their expectations and work conditions on all dimensions except for workload.

Moreover, to explore the possible reasons for these findings, formal semi-structured interviews were also conducted with 18 volunteer EFL instructors. The interview questions were about six areas of work life and work environment of the instructors. Qualitative data were grouped under six areas of work life: Workload, control, reward, community, fairness and values.

In terms of workload, quantitative data of the research study revealed that only higher levels of EE induced a significantly lower match between teacher expectations and workload. Qualitative data from the interviews explored the possible reasons of mismatches between teachers' expectations and real workload.

Workload is OK. I just teach in the morning and I am not asked to prepare written lesson plans, materials or contribute to testing procedure, so I have sufficient time to check my students' portfolios, exams, prepare my lessons, and read some articles for my M.A. (Instructor 2)

Two instructors actually stated that it is not the quantity of workload but the quality and meaningfulness of work that matters for them. Still, there were also other instructors who were affected by their workload negatively. First, substitute classes and extra duties such as invigilation were a big problem for some of the instructors. These instructors weren't worried about the work to be done but they were against the idea that they had to do someone else's work.

Second, time spent at school was also a factor of a mismatch. Many instructors agreed that they didn't need to spend time at school more than necessary. Instructors also reflected on their workload about grading (especially during intense exam periods). Although many felt exhausted by the exam periods, they knew that this was only for some temporary time.

20 hours of teaching in a week is a lot. Plus, you have to be at work from 8am to 5pm. combining those two is too much. No sense to be at work when you have no class. (Instructor 3) 
Another factor that affected teachers' workload was feedback sessions or tutorial hours. These two were also related to students' level. The student profile and level, and its effect on instructors were also obvious from the other comments that they made. Unmotivated, low level students as well as very high level students were some exhaustion factors for the instructors.

When there are a lot of things to do but time is limited I feel stressed. Giving one to one feedback makes me feel exhausted at work. (Instructor 16).

Some of the instructors also stated that pacing issues also made them feel exhausted. In schools where the instructors were observed, the elements of lesson planning and pre and post observation processes were also some stress factors.Many instructors thought of administration tasks at preparatory schools a source of stress and exhaustion. Finally, some instructors who had extra job responsibilities, for example the ones who worked at testing office, stated that they sometimes don't have enough time to carry out their duties.

Second area of work life was control. Quantitative data results indicated that the match between work conditions and personal expectancies in terms of control was better in those teachers who reported lower levels of burnout in all dimensions. Interviews with teachers also indicated that some teachers were quite satisfied about their control on the job and some were not.

Some positive comments made by instructors were about their autonomy in their decisions, the help that they can get from the coordinators and democratic nature of making decisions. On the other hand, most of the instructors stated that they cannot be a part of decision making processes in many areas.

I can generally make my own decisions in my current work. But here, the system is multifaceted which offers you the autonomy but at the same time, you need to be compatible with the other teachers. (Instructor 13)

Third work life area was reward. Quantitative data results indicated that the match between work conditions and personal expectancies in terms of reward was worse in those teachers who reported higher levels of burnout in all dimensions. Qualitative results also indicated that teachers were quite unhappy about the worth of their efforts. For some teachers, it was a mix of feelings in both ways. For some instructors, on the other hand, rewarding didn't even exist. These comments were mainly about policies of administration.

My colleagues seem to realize my efforts and they appreciate. However, very few of them can be discouraging by pointing out that there is no need to do fancy stuff that they claim I'm doing. (Instructor 17)

In terms of community, when the quantitative data is examined, it can be seen that except for RPA dimension of burnout, teachers with high and low burnout didn't significantly differ. The interviews supported this finding, as well. Many of the instructors expressed positive attitudes about their community, which meant a match between expectations and reality.

Fortunately, the personal and professional relationship among instructors is positive and collaborative. I have also some colleagues that I really trust and get on well and spend time out of the school, too. So, I think me and my colleagues here are good team players. (Instructor 14)

As for fairness, quantitative data results indicated that the match between work conditions and personal expectancies was better in those teachers who reported lower levels of burnout in all dimensions. Qualitative data revealed that fairness issues among instructors generally originated from distribution of workload. Instructors found it unfair to do duties that they 
thought they were not responsible for. These were extra invigilation duties, marking of quizzes and teaching different levels

It is not fair to teach 24 students in different levels as you not only follow weekly pacing for each level but also prepare extra materials for reading-writing courses, on the other hand, some other teachers are teaching only one level with 10-12 students. (Instructor 5).

\section{Discussion}

Quantitative data of the research study revealed that only higher levels of emotional exhaustion induced a significantly lower match between teacher expectations and workload. When qualitative data are taken into consideration, it can be seen that instructors find the workload acceptable. However, quality and meaningfulness of the workload were important for them. They didn't want to carry out duties that made no sense. Irrelevant assessment tasks and activities that didn't foster student learning were examples of these. This aspect of workload can also relate to area of reward, where lack of intrinsic rewards cause mismatches. Maslach et al (2001) suggested that teachers can be taught how to cope with overload and how to relax but it is more effective "if people value the work and they feel they are doing something important, or if they feel well-rewarded for their efforts" (p.419). Therefore, institutions may consult teachers about effectiveness and meaningfulness of the activities and tasks carried out in the classroom. This way, they will be able to have the chance to reflect on what they do and have more pleasure in the process.

Grading during intense exam periods, feedback sessions and tutorial hours were also some factors for exhaustion. As human interaction is one of the main causes of burnout, it can be seen that these times mentioned above are when teachers have to deal with their colleagues (to decide on a grade) and students (to give one to one feedback) intensely. Therefore, it is no wonder that they had feelings of exhaustion. Furthermore, unmotivated student profile also affected instructors in a negative way. To deal with administrative tasks, institutions may try to find some other ways to remove the burden from teachers. For instance, a unit responsible for copying of materials or an efficient online system where the attendance and grade entry made easy could help these teachers. Professional development units may help teachers by suggesting ideas to motivate their students.

In some preparatory schools where observations were carried out by administration, teachers also felt under stress and exhausted. They mentioned that preparation process for the observations took a long time. This finding is in accordance with Cordes\& Dougherty's (1993) findings which stated that work overload accompanied with time pressure is strongly related to exhaustion dimension of burnout. Therefore, constructive comments by the development units and administration can be of help to these teachers. Teachers should also have the opportunity to develop their skills with the help of teacher trainers in their school before administrative observations take place. Feelings of readiness can reduce these teachers' stress and exhaustion.

In terms of control, there was a significant difference between low and high burnout teachers on all dimensions of burnout. Interviews also shed some light on the quantitative data. Some teachers were quite satisfied with their control over work and some weren't. Being not part of the decision making processes that directly affected teachers' lesson planning was the core reason of mismatch. Although teachers had freedom in their actual teaching in class, most of the instructors couldn't take part in planning of pacing, materials chosen by the institution, and strict standardization criteria posed on them. It was clear that these issues directly affected instructors' in-class performance. Not having enough autonomy, on the other hand, 
made them more exhausted.

EFL instructors' perceptions of reward generally focused on the feedback from administration. Even the ones, who were happy with it, stated that it only happened once a year in appraisal meetings. For others, it didn't even exist. It can be inferred that EFL instructors needed appreciation both from their colleagues and administration.

Except for reduced personal accomplishment dimension, high and low burnout teachers didn't differ statistically in terms of community. This was also observed in interviews. Instructors shared their personal and professional ideas among themselves, though in small groups. Mismatches occurred when teachers wanted professional development and feedback on their teachings and this might be the reason why there was a significant difference between teachers with high and low burnout in terms of reduced personal accomplishment. As a result, providing English teachers with professional developmental programs can help them find self-efficacy in their teaching.

Mismatches in fairness generally emerged from unequal distribution of workload among instructors. Extra invigilation duties, marking of extra quizzes, last-minute substitutions, and teaching different levels in the same module were the main reasons for fairness issues. Some instructors also demanded free transport and free meal, which were their basic needs.

Mismatches in values occurred in these three areas: Providing better teaching standards to students, professional development opportunities, and commercialization of the universities. In fact, these three areas are closely related to one another. Commercialization of the universities ignores better standards of teaching and focuses on making more money with more students, which leads to ignorance of professional development units at institutions.

\section{Pedagogical Implications}

Findings reported in this study provide some pedagogical implications for both teachers and administrative staff. Awareness of burnout phenomenon can help teachers develop some individual coping strategies and deal with job burnout. Administration, on the other hand, may promote team work and close professional connections among teachers. Administrative staff should also provide cooperative decision making processes such as weekly meetings and periodical online feedbacks on different units at school. Moreover, personal development units and help of professional teacher trainers may be of great help for teachers. When teachers lack sense of social support, they may consult these teacher trainers.

\section{Recommendations for Future Research}

This study has several recommendations for further research. First, the present study constituted only 81 volunteer instructors for quantitative data and 18 volunteer instructors for qualitative data. Thus, having a larger sample from more than five universities could give more representative results for characteristics of burnout and areas of work life.

Second, the researcher didn't know whether the interviewees were high or low burnout teachers in three dimensions of burnout. Further research may consider grouping the interviewees according to their burnout scores and compare comments of these teachers and statistical data.

Finally, some demographic factors (e.g., gender, marital status, and years of experience) can 
also be investigated in relation to six work areas and high and low burnout teachers.

\section{Conclusion}

In summary, teachers with high and low burnout in all dimensions significantly differ in terms of values variable. High burnout teachers related significantly weaker match between their expectations and work conditions on values. Teachers' comments explicitly indicated that professional development played an important role in teachers' perceptions in relation to their workplace. Some of the teachers were quite happy about the opportunities in their institutions. However, some of the instructors' expectations and their actual work environment didn't match in terms of teacher development. Moreover, qualitative data yielded two interesting results: First, fairness and workload are seemed to be related for these instructors. EFL instructors generally didn't mind having much work to do but they were against the idea of doing someone else's work. Second, they were quite happy with the community they were in but they had some problems with administration. Still, they mostly commented on positively about the personal relationships with their colleagues and administration. Statistical data were also in line with this finding.

\section{References}

Atila, E. (2014). The relationship between burnout and job satisfaction levels of English teachers and instructors. Unpublished MA Thesis, Çanakkale Onsekiz Mart University, Çanakkale.

Baysal, A. (1995). Lise ve dengi okul öğretmenlerinde meslekten tükenmişliğe etki eden faktörler [Factors affecting teachers' professional burnout among high school teachers].Unpublished $\mathrm{PhD}$ Thesis, Dokuz Eylül University, Izmir.

Borg, M. G., \& Riding, R. (1991).Occupational stress and satisfaction in teaching. British Educational Research Journal, 17, 263-281.

Burke, R. J., Greenglass, E. R., \&Schwarzer, R. (1996). Predicting teacher burnout over time: Effects of work stress, social support, self-doubts on burnout and its consequences. Anxiety, Stress, and Coping: An International Journal, 9(3), 261-275.

Byrne, B. M. (1994). Testing for the validity, replication, and invariance of casual structure across elementary, intermediate, and secondary teachers. American Research Journal, 31, 645-673.

Byrne, B. M. (1999). "The nomological network of teacher burnout: A literature review and emprically validate model.” In R. Vandenberghe, \& A. M. Huberman (Eds.), Understanding and preventing teacher burnout: A sourcebook of international research and practice (pp. 15-37). Cambridge: Cambridge University Press.

Cherniss, C. (1980). Staff burnout: Job stress in the human services. Beverly Hills, CA: Sage.

Cihan, B. B. (2011). Farklı illerde çalışan ilköğretim okullarında görevli beden eğitimi öğretmenlerinin, mesleki tükenmişlik düzeylerinin incelenmesi ve karşılaştırılması. [Investigation and comparison of burnout levels of physical education teachers' working at the primary schools and in different cities]. Unpublished MA Thesis, Gazi University, Ankara.

Cordes, C. L., \& Dougherty, T. W. (1993).A review and integration of research on job burnout. Academy of Management Review, 16, 621-658.

Cottrell, R., \& McKenzie, J. F. (2010).Health promotion \& education research methods: Using the five chapter thesis/dissertation model. Jones \& Bartlett Publishers.

Creswell, J. W. (2003). Research design: Qualitative, quantitative, and mixed methods approaches (2. ed.). Sage publications. 
Demir, K. (1997). İlköğretimokullarındagörevyapanöğretmenlerinveokulyöneticilerinin örgütsel stress kaynakları [Sources of stress in school managers and teachers in secondary schools]. Unpublished PhD. Thesis, Ankara University, Ankara.

Freundenberger, H. J. (1974). Staff burnout.Journal of Social Issues, 30, 159-165.

Girgin, G. (1995). İlkokul öğretmenlerinde meslekten tükenmişliğin gelişimini etkileyen değişkenlerin analizi ve bir model önerisi: İzmir ili kırsal ve kentsel yore karş1laştırmas1. [Analysis of the factors affecting the burnout process in primary school teachers and a model suggestion]. Unpublished PhD. Thesis, DokuzEylül University, Izmir.

Kulavuz, D. (2006). Exploring burnout and participation in professional learning activities among university prep Turkish EFL instructors. Unpublished MA Thesis, Boğaziçi University, Istanbul.

Lavian, R. H. (2012). The impact of organizational climate on burnout among homeroom teachers and special education teachers in mainstream schools. Teachers and Teaching: theory and practice, 18(2), 233-247.

Leiter, M. P., \&Maslach, C. (2011).Areas of work life survey manual. California: Mind Garden Inc.

Maslach, C., \& Jackson, S. E. (1981).The measurement of experienced burnout.Journal of Occupational Behaviour, 2, 99-113.

Maslach, C., \& Jackson, S. E. (1986).Maslach burnout inventory: Second edition. Palo Alto, CA: Consulting Psychologists Press.

Maslach, C., \&Leiter, M. P. (1999).“Teacher burnout: a research agenda”. In R. Vandenberghe, \& A. M. Huberman (Eds.), Understanding and preventing teacher burnout: A source book of international research and practice (pp. 295-303).

Cambridge: Cambridge University Press.

Maslach, C., Jackson, S. E., \&Leiter, M. P. (1996). Maslach burnout inventory manual. (3rd Ed.). Palo Alto, CA: Consulting Psychologists Press.

Maslach, C., \& Pines, A. (1984). Experiencing social psychology: Readings and projects. USA: Knopf.

Polatc1, S. (2007).Tükenmişlik sendromu ve tükenmişlik sendromuna etki eden faktörler:Gazi Osmanpaşa Üniversitesi akademik personeli üzerine bir araştırma. [Buronour syndrome and he factors affecting the syndrome: An investigation on the academic staff at Gazi Osmanpasa University]. Unpublished MA Thesis, Gaziosmanpaşa University, Tokat.

Saldana, J. (2009). The coding manual for qualitative researchers. Los Angeles,CA: SAGE.

Schaufeli, W. B., Leiter, M. P., \&Maslach, C. (2009). Burnout: 35 years of research and practice. Career Development International, 14, 204-220.

Seferoğlu, S. S., Yıldız, H., \&Yücel, Ü. A. (2014). Teacher's burnout: Indicators of burnout and investigation of the indicators in terms of different variables. Education and Science, 39, 349-364.

Vaughan, L. (2001). Statistical methods for the information professional: A practical, painless approach to understanding, using, and interpreting statistics. Medford: NJ Information Today. 